\title{
Defective Postbinding Lysis Underlies the Impaired Natural Killer Activity in Factor VIII-treated, Human T Lymphotropic Virus Type III Seropositive Hemophiliacs
}

\author{
Michael Katzman and Michael M. Lederman \\ Department of Medicine, Case Western Reserve University School of Medicine, and \\ University Hospitals of Cleveland, Cleveland, Ohio 44106
}

\begin{abstract}
We investigated the diminished natural killer (NK) activity in human T lymphotropic virus type III (HTLV-III) seropositive hemophiliacs. Despite normal percentages of NK cells, lymphocytes from five hemophiliacs showed impaired NK activity against K-562 tumor cells in 4-h chromium release microcytotoxicity assays. For example, at an effector-to-target cell ratio of $10: 1$, cells from patients caused $21.7 \pm 2.5 \%$ lysis of tumor targets compared with $47.9 \pm 5.1 \%$ lysis by cells from controls (mean \pm SEM, $P<0.005$ ). Cells from patients were as cytotoxic in $18 \mathrm{~h}$ as were cells from controls in $4 \mathrm{~h}$. Binding to tumor targets was not impaired since $11.0 \pm 1.5 \%$ of cells from patients and $11.1 \pm 1.3 \%$ of cells from controls bound to K-562 cells. Patients' binding cells, however, showed defective killing of attached tumor cells at all time points tested from 0 to $18 \mathrm{~h}$. At $4 \mathrm{~h}$, for example, patients' cells had lysed $10.9 \pm 2.1 \%$ of attached tumor cells compared with $26.3 \pm 3.3 \%$ lysis by controls' cells ( $P$ $<0.005)$. The percentage of lymphocytes which were active NK cells (i.e., cells that bound and lysed a tumor cell) was always lower for patients than for controls $(1.17 \pm 0.25 \%$ vs. $2.82 \pm 0.33 \%$, $P<0.005)$. Two methods for estimating recycling of effector cells against multiple target cells demonstrated that active NK cells from patients could recycle as well as those from controls ( 3-4 times in $4 \mathrm{~h}$ ). Mixing experiments showed no evidence for cellular suppression of NK activity. The lytic function of NK cells from HTLV-III seropositive hemophiliacs is thus heterogeneous. This is characterized by a defect in post-binding lysis, with relative sparing of binding capability and recycling capacity.
\end{abstract}

\section{Introduction}

Hemophiliacs, although accounting for fewer than $1 \%$ of all cases of the acquired immunodeficiency syndrome (AIDS) ${ }^{1}$ (1), are

This work was presented in part at the American Federation for Clinical Research Midwest Section meeting, Chicago, IL; November 1985.

Address correspondence to Dr. Lederman, Division of Infectious Diseases, University Hospitals of Cleveland, 2074 Abington Road, Cleveland, OH 44106.

Received for publication 6 September 1985

1. Abbreviations used in this paper: AIDS, acquired immunodeficiency syndrome; ARI, apparent recycling index; CRA, chromium release assay; E:T, effector to target ratio; FCS, fetal calf serum; HTLV-III, human T lymphotropic virus type III; LU, lytic units; MRC, maximal recycling capacity; NA, nonadherent lymphocytes; NK, natural killer; $V_{\max }$, maximum number of target cells that can be killed in $4 \mathrm{~h}$ by $1 \times 10^{5}$ effector cells.

J. Clin. Invest.

(C) The American Society for Clinical Investigation, Inc.

0021-9738/86/04/1057/06 $\$ 1.00$

Volume 77, April 1986, 1057-1062 currently the group with the highest nationwide attack rate. One of every 200 Americans with classic hemophilia (Factor VIII deficiency) has developed $\operatorname{AIDS}(2,3)$, and upwards of $80 \%$ of patients treated with Factor VIII concentrates are seropositive for antibody to the human T lymphotropic virus type III (HTLVIII) $(2,4)$. Hemophiliacs, like other groups at risk for AIDS, have been noted to have immunologic abnormalities indicative of impaired cell-mediated immunity. In particular, natural killer (NK) cell activity, as measured by spontaneous cytolytic activity against chromium-labeled tumor cells, has often been shown to be diminished in apparently healthy hemophiliacs (5-8). It has previously been reported that the diminished NK activity of these patients was not due to diminished numbers of NK cells as measured by large granular lymphocyte morphology or surface phenotype using the monoclonal antibodies OKM1 and Leu 11a. Furthermore, depletion of adherent cells (monocytes) or the addition of alpha interferon, gamma interferon, or interleukin 2 did not restore NK activity to normal (9).

In this study, we attempted to localize the defect in NK activity that is present in Factor VIII concentrate-treated, HTLVIII seropositive, asymptomatic hemophiliacs. Binding of effector cells to the K-562 tumor target cell appeared to be normal, but fewer bound cells expressed lytic function. Those NK cells that were active killers could recycle and lyse other targets during chromium release assays (CRA). Cell mixing experiments failed to demonstrate evidence of a suppressor mechanism. These experiments have demonstrated a functional heterogeneity among NK cells of HTLV-III seropositive hemophiliacs characterized by defective postbinding lysis.

\section{Methods}

Subjects. Patients with classic hemophilia (ages 23-39 yr old) who on previous testing had demonstrated impaired NK activity were selected for further study. All were seropositive for antibody to HTLV-III by enzyme-linked immunosorbent assays (4). All were asymptomatic, but two had unexplained lymphadenopathy, and one had recovered from idiopathic thrombocytopenia (10) (he had been off corticosteroids for $>1 \mathrm{yr}$ ). Age-matched males who did not belong to an AIDS-risk group were selected as controls.

Effector cells. After informed consent was obtained, peripheral blood mononuclear cells (PBMC) were obtained from heparinized blood by Ficoll-Hypaque (Pharmacia Fine Chemicals, Piscataway, NJ) density sedimentation. Adherent cells were removed by incubation on acidwashed nylon wool (Fenwal Laboratories, Deerfield, IL) columns for 30 min at $37^{\circ} \mathrm{C}$ in RPMI-1640 medium (M.A. Bioproducts Inc., Walkersville, MD) plus $10 \%$ heat-inactivated fetal calf serum (FCS) (KC Biologicals, Inc., Lenexa, KS), and the nonadherent cells were collected by dropwise elution.

Target cells. The erythroleukemia K-562 cell line was maintained in culture in RPMI medium, supplemented with $4 \mathrm{mM}$ L-glutamine (KC Biologicals); penicillin, $50 \mathrm{U} / \mathrm{ml}$ (Eli Lilly and Co., Indianapolis, IN); gentamicin, $5 \mu \mathrm{g} / \mathrm{ml}$ (Schering Corp., Kenilworth, NJ); and 15\% FCS; with twice-weekly medium changes. 
Chromium release assay (CRA). One million K-562 cells were labeled by incubation with $0.1 \mathrm{mCi}$ sodium chromate (sp act, $1 \mathrm{mCi} / \mathrm{ml}$; New England Nuclear, Boston, MA) in normal saline for $1-2 \mathrm{~h}$ at $37^{\circ} \mathrm{C}$ in $5 \% \mathrm{CO}_{2}$, washed four times in medium (RPMI with $10 \% \mathrm{FCS}, 2 \mathrm{mM}$ L-glutamine, penicillin, and gentamicin), and suspended at $1 \times 10^{5}$ cells/ $\mathrm{ml}$. 5,000 Cr-labeled K-562 targets in $50 \mu$ l were delivered into triplicate round bottom microtiter wells (Becton Dickinson \& Co., Oxnard, CA). Effector cells were delivered in $100 \mu$ medium to achieve final effectorto-target (E:T) ratios of 40:1, 20:1, 10:1, and 5:1. Plates were centrifuged at $50 \mathrm{~g}$ for $5 \mathrm{~min}$, incubated at $37^{\circ} \mathrm{C}$ in $5 \% \mathrm{CO}_{2}$ for 4 or $18 \mathrm{~h}$, and then, centrifuged at $150 \mathrm{~g}$ for $10 \mathrm{~min}$. Radioactivity in $50 \mu \mathrm{l}$ of supernatant was then measured using a gamma counter. Percent specific ${ }^{51} \mathrm{Cr}$-release, or percent lysis, was calculated as:

$\frac{\mathrm{cpm} \text { experimental release }-\mathrm{cpm} \text { spontaneous release }}{\mathrm{cpm} \text { total release }-\mathrm{cpm} \text { spontaneous release }} \times 100$

Spontaneous release was determined in the presence of medium without effector cells, and total release was determined by addition of detergent ( $1 \%$ sodium dodecyl sulfate) (Sigma Chemical Co., St. Louis, MO). Spontaneous release was usually $<10 \%$ of maximum release at $4 \mathrm{~h}$, and $<20 \%$ of maximum release at $18 \mathrm{~h}$. In some experiments, linear regression was used to define a straight line of "percent lysis" versus "log (effector cell number)," and lytic units (LU) were calculated as the number of effector cells required to cause $30 \%$ lysis, divided into $1 \times 10^{7}$ cells (11).

Single-cell conjugate in agarose assay. We used a modification of a previously reported method (12). Equal numbers $\left(1 \times 10^{6}\right)$ of effector and target cells were mixed in $1 \mathrm{ml}$ medium in $12 \times 75$-mm test tubes, incubated at $37^{\circ} \mathrm{C}$ for $10-20 \mathrm{~min}$, and then centrifuged at $250 \mathrm{~g}$ for 5 min to promote the formation of conjugates. Half the supernatant was removed and the cells were gently resuspended by aspirating 10 times with a 9-in Pasteur pipette. One drop of the suspension was then placed onto triplicate microscope slides and the percentage of effector cells forming conjugates with target cells was counted in a blinded fashion.

$1 \mathrm{ml}$ of liquified $0.5 \%$ agarose (Agarose Indubiose A45; Accurate Chemical and Scientific Corp., Westbury, NY) was then added to the remaining cell suspension and pipetted twice, and then spread onto replicate slides which had been precoated with $1.0 \%$ agarose. After the agarose had solidified, slides were immersed in chamber jars containing medium at $37^{\circ} \mathrm{C}$ in $5 \% \mathrm{CO}_{2}$. Slides from patients and controls were separated to prevent the possible transfer of soluble factors. At various time points, slides were removed, stained with $0.2 \%$ trypan blue (Matheson, Coleman and Bell Manufacturing Chemists, Norwood, $\mathrm{OH}$ ) for $5 \mathrm{~min}$, destained with RPMI for 5-10 min, then fixed with $0.2 \%$ paraformaldehyde (Fisher Scientific Co., Fair Lawn, NJ) for 5 min. A cover slip was then added and slides were viewed at $400 \times$ by light microscopy and scanned for conjugates. The percentage of 100 conjugates which consisted of a dead (blue) target attached to a living effector cell was counted in a blinded fashion. Correction for spontaneous target death was made by subtracting the percentage of targets which were dead on parallel slides which had no effector cells. Spontaneous death rates were usually much less than $10 \%$ at all time points. The percent active NK cells was calculated as follows: (percent target binding cells from the wet mounts) $\times$ (percent lytic conjugates in agarose at the 4-h time point) $\times 100(13)$.

Derivation of maximal recycling capacity (MRC). We applied the methods of Ullberg and Jondal (13) to estimate recycling. Data from the 4-h CRA were displayed on a Michaelis-Menten curve as the number of killed targets (calculated as percent lysis $\times$ the number of initial targets) vs. the number of initial targets. Because all. wells contained 5,000 targets, the "initial number of targets" was determined by normalizing the number of effectors to $1 \times 10^{5}$. For example, at $E: T=10: 1$, each well had 50,000 effectors and 5,000 targets, and this was normalized to 100,000 effectors and 10,000 targets to maintain the same E:T ratio. The percent lysis for $E: T=10: 1$ was then assigned to 10,000 initial targets. Data were next displayed on a Lineweaver-Burk double reciprocal plot of $1 /$ number of killed targets vs. $1 /$ number of initial targets. The straight line obtained crosses the $y$-axis at the reciprocal of the maximum number of target cells $\left(V_{\max }\right)$ that could be killed by $1 \times 10^{5}$ effectors in $4 \mathrm{~h}$ even if the number of initial targets was infinite. Division of $V_{\max }$ by the number of active NK cells in $1 \times 10^{5}$ effectors yields the MRC, a theoretical number which has value in comparing effector cell populations.

Derivation of apparent recycling index (ARI). Although the MRC as derived above has been used by others $(14,15)$ and yields consistent findings, application of an enzyme kinetics model requires certain assumptions that may not hold for cellular systems. In particular, the substrate (target) concentration should be much larger than the enzyme (effector) concentration (16). We therefore devised an alternative method to estimate recycling. A single cell conjugate assay was performed with $\mathrm{E}: \mathrm{T}=5: 1$ and the percentage of targets which had at least one effector cell bound to it was ascertained in blinded, triplicate samples. This was then multiplied by the percentage of conjugates which were lytic in the 4-h agarose assay at E:T $=5: 1$. The product is the percent of target cells lysed in $4 \mathrm{~h}$ when only one cycle of binding is permitted. Division of this value into the percent lysis obtained from the corresponding E:T ratio in the 4-h fluid-phase CRA directly yields the ARI.

Statistical analysis. Results are expressed as mean \pm SEM. Unless otherwise indicated, comparisons were made using the two-tailed $t$ test of independent means (Student's $t$ test).

\section{Results}

$\dot{C} R A$. In a 4-h CRA, nonadherent lymphocytes from each patient demonstrated less cytotoxicity than did lymphocytes of his matched control (Fig. 1). The mean lysis for the two groups were different $(P<0.01)$ at each $\mathrm{E}: \mathrm{T}$ ratio. The mean curve of the patients had $136 \mathrm{LU}$ compared with $508 \mathrm{LU}$ for the mean curve of the controls. In $18 \mathrm{~h}$, cells from patients still showed less cytotoxicity than did cells from controls, although the two curves approached each other at the higher E:T ratios $(P<0.005$ for $\mathrm{E}: \mathrm{T}=5: 1$ and for $\mathrm{E}: \mathrm{T}=10: 1, P<0.05$ for $\mathrm{E}: \mathrm{T}=20: 1$ and for $\mathrm{E}: \mathrm{T}=40: 1$, paired $t$ test). NK activity of cells from patients in $18 \mathrm{~h}$ was comparable to that of cells from controls in $4 \mathrm{~h}$.

Single cell assay. When effectors and targets were mixed, cells from patients and controls formed the same number of conjugates with target cells $(11.0 \pm 1.5 \%$ in the patients vs. $11.1 \pm 1.3 \%$ in the controls) (Table I). When immobilized in agarose and tested for lysis of attached targets by trypan blue uptake, cells from patients showed significantly fewer lytic conjugates at all time points tested (Fig. 2). In particular, at $4 \mathrm{~h}$, patients had $10.9 \pm 2.1 \%$ lytic conjugates, and controls had $26.3 \pm 3.3 \%$ lytic conjugates $(P<0.005)$. All five patients had fewer active NK cells at $4 \mathrm{~h}$ than the lowest control (Table I). The difference in

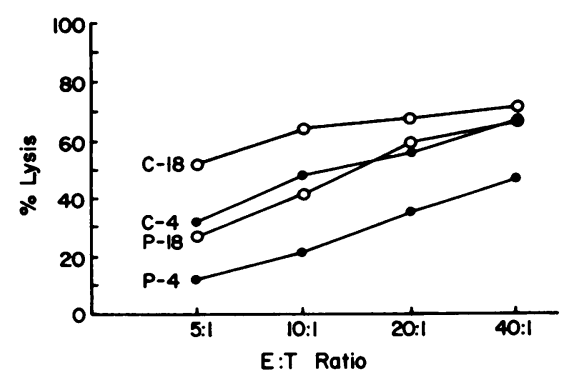

Figure 1. Cytotoxicity in CRA. Nonadherent lymphocytes (NA) were tested against ${ }^{51}$ chromium-labeled K-562 tumor cells. Each point represents the mean of values obtained from five patients or controls and shows the percent lysis at a given E:T ratio. In $4 \mathrm{~h}$, cells from patients $(P-4)$ showed less cytotoxicity than did cells from controls (C-4) at each E:T ratio $(P<0.01)$. After $18 \mathrm{~h}$, cells from patients $(P-18)$ still had less cytotoxicity than did cells from controls $(C-18)(P<0.05)$, but the $\mathrm{P}-18$ curve is not different from the $\mathrm{C}-4$ curve. 
Table I. Calculation of Percent Active NK Cells

\begin{tabular}{|c|c|c|c|c|}
\hline Experiment no. & Subject & Percent effectors bound & $\begin{array}{l}\text { Percent lytic } \\
\text { conjugates at } 4 \mathrm{~h}\end{array}$ & $\begin{array}{l}\text { Percent active } \\
\text { NK cells at } 4 \mathrm{~h}\end{array}$ \\
\hline \multirow[t]{2}{*}{1} & Patient 1 & $13.7 \pm 0.9$ & 14.0 & 1.92 \\
\hline & Control 1 & $10.6 \pm 1.8$ & 33.0 & 3.50 \\
\hline \multirow[t]{2}{*}{2} & Patient 2 & $6.2 \pm 0.8$ & 11.0 & 0.68 \\
\hline & Control 2 & $7.7 \pm 1.4$ & 34.0 & 2.62 \\
\hline \multirow[t]{2}{*}{3} & Patient 3 & $9.2 \pm 2.8$ & 16.5 & 1.52 \\
\hline & Control 3 & $9.0 \pm 1.8$ & 21.5 & 1.94 \\
\hline \multirow[t]{2}{*}{4} & Patient 4 & $13.8 \pm 3.5$ & 8.0 & 1.10 \\
\hline & Control 4 & $14.0 \pm 1.6$ & 17.0 & 2.38 \\
\hline \multirow[t]{5}{*}{5} & Patient 5 & $12.1 \pm 2.4$ & 5.0 & 0.61 \\
\hline & Control 5 & $14.1 \pm 3.7$ & 26.0 & 3.67 \\
\hline & Patients & $11.0 \pm 1.5$ & $10.9 \pm 2.1$ & $1.17 \pm 0.25$ \\
\hline & Controls & $11.1 \pm 1.3$ & $26.3 \pm 3.3$ & $2.82 \pm 0.33$ \\
\hline & $P$ value & $\mathrm{NS}^{*}$ & $P<0.005$ & $P<0.005$ \\
\hline
\end{tabular}

Equal numbers of NA (effectors) and K-562 tumor cells were mixed and the percent of effectors which bound a tumor cell was counted (results expressed as mean \pm SD of triplicate samples). Cell mixtures were immobilized in agarose, and trypan blue was added $4 \mathrm{~h}$ later. Percent lytic conjugates is the percent of 100 bound tumor cells which took up the stain. Percent active NK cells is the product of the preceding two columns and represents the percent of effector cells which bound and killed a tumor cell in $4 \mathrm{~h}$. Group data are shown as mean \pm SEM. ${ }^{*} \mathrm{NS}$, not significant.

active NK cells between the groups (patients: $1.17 \pm 0.25 \%$; controls: $2.82 \pm 0.33 \%)$ was statistically significant $(P<0.005)$.

Recycling of effector cells. Fig. 3 shows the CRA data from one experiment (number 4) where the axes, instead of being labeled "percent lysis" vs. "E:T ratio," were labeled "number of killed targets" vs. "number of initial targets" (see Methods). In this form a maximal value for killed targets was approached as the number of initial targets became very large. Fig. 4 shows these data expressed as a double reciprocal plot with the axes 1/ number of killed targets vs. 1 /number of initial targets. The two lines obtained in this experiment, as in the four others, had similar slopes and $r$ values $>0.96$ (Table II). The maximum number $\left(V_{\max }\right)$ of targets that could be killed in $4 \mathrm{~h}$ by $1 \times 10^{5}$ effector cells was always lower for the patients than for the con-

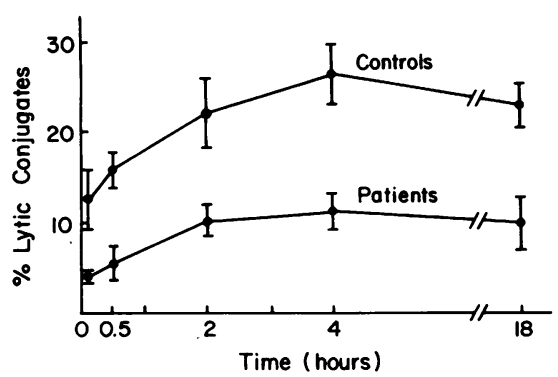

Figure 2. Cytotoxicity in agarose assays. Equal numbers of NA and K562 target cells were allowed to form conjugates, immobilized in agarose, and then examined for lysis of bound targets by trypan blue uptake at various time points. The percent lytic conjugates is expressed as mean \pm SEM for each group. The differences between patients and controls were significant at each time point $(t=0.1 \mathrm{~h}, P<0.05 ; t$ $=0.5 \mathrm{~h}, P<0.01 ; t=2 \mathrm{~h}, P<0.025 ; t=4 \mathrm{~h}, P<0.005 ; t=18 \mathrm{~h}, P$ $<0.02$ ). trols (Table II). The difference between the groups was statistically

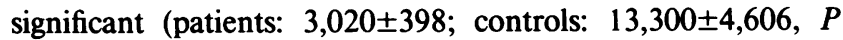
$<0.05$, paired $t$ test). $V_{\max }$ values divided by the number of active NK cells present in $1 \times 10^{5}$ effectors yielded the MRC (Table II), which did not differ significantly between the groups (patients: $3.1 \pm 0.8$; controls: $4.4 \pm 1.1$ ). An alternative method for estimating recycling (Table III) yielded similar results for the ARI (patients: $3.8 \pm 0.5$; controls: $3.7 \pm 0.7$ ).

Cell mixing experiments. To test the possibility that inhibiting or competitively binding cells interfered with killing by patients' cells, we performed CRA in which the effector cell population consisted of $50 \%$ patient cells and $50 \%$ control cells. The observed LU were then compared with the mean of the LU for the patient and the control. The results of such mixing experiments (Table IV) did not suggest any interference with killing by patient nonadherent cells or by patient PBMC (which contain adherent cells).

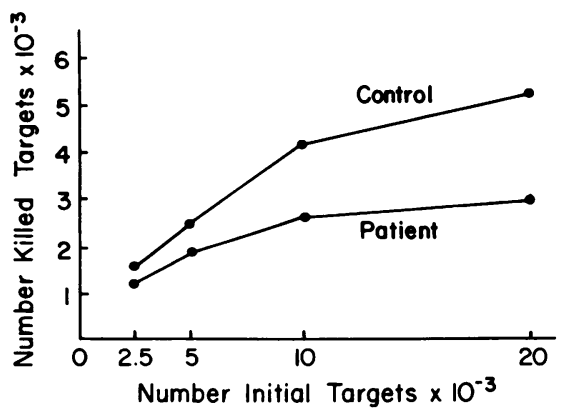

Figure 3. Tumor killing curves from a patient and control. The CRA data for lymphocytes of patient number 4 and his matched control are here expressed as the number of killed targets versus the number of initial targets (see Methods). As the number of initial targets becomes very large, the number of killed targets approaches a maximum. 


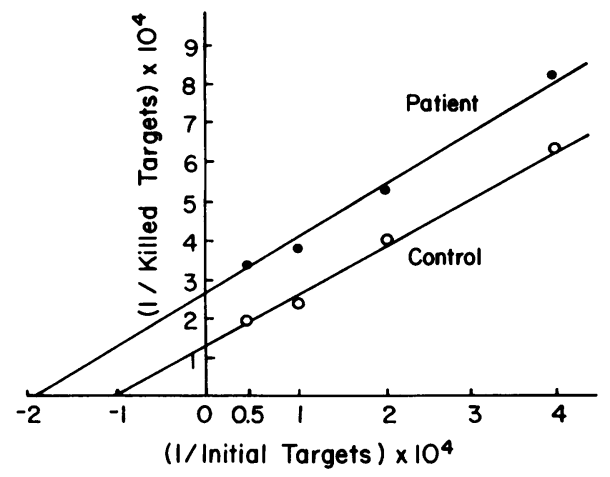

Figure 4. Killing curves expressed as double reciprocal plots. The killing data from a patient and his control form two approximately parallel lines. The reciprocals of the y-intercepts of these lines represent the maximum number of killed targets approached in Fig. 3.

\section{Discussion}

A broad array of immune dysfunction and abnormalities has been described in AIDS (17). In particular, NK activity has been uniformly depressed in patients with AIDS and in many asymptomatic homosexuals at risk for AIDS (18-20). Similarly, studies of apparently healthy hemophiliacs treated with Factor VIII concentrates have often $(5,6)$ shown depressed NK activity. This group is particularly well suited for study because such individuals generally lack the comorbidity of the sexually transmitted diseases present in homosexuals or the pharmacologic influences present among intravenous drug abusers.

In the current study, our selected patients demonstrated less NK activity than age-matched controls in 4-h CRA despite apparently normal binding of lymphocytes to tumor cells. After $18 \mathrm{~h}$ in culture, cells from patients killed as well as cells from controls had killed in $4 \mathrm{~h}$. This suggested that in $18 \mathrm{~h}$ either more bound cells killed their targets or that some active cells recycled and killed several targets. When immobilized in agarose to prevent recycling, cells from patients showed significantly less cytotoxicity at all time points (Fig. 2). In particular, bound cells did not show increased killing between 4 and $18 \mathrm{~h}$. Two methods to estimate recycling showed that cells from patients recycled as well as cells from controls, 3-4 times in $4 \mathrm{~h}$. These experiments strongly suggest the presence of a defect in postbinding lysis that is evident in the first few hours of assay.

Although lymphocytes from patients and controls formed conjugates with tumor targets with equal frequency, it was not clear that NK cell binding to targets was normal. Conceivably, a competing cell displaced and prevented some NK cells from binding to targets, resulting in the same observed total binding by the lymphocyte population (about $11 \%$ in these studies) but less lysis. Our attempts to directly identify lymphocytes forming conjugates by purification of conjugates, Giemsa staining of cytospin preparations, or immunofluorescent staining of conjugates were not reproducible or always internally consistent. Nonetheless, several lines of evidence make competition/suppression an unlikely explanation for the diminished NK activity in these patients. First, since only a small minority of K-562 targets was bound in each cycle of conjugate formation, displacement alone should not have appreciably affected killing. An effective suppressor mechanism would require that the displaced NK cells not bind to the remaining comparably susceptible target cells, i.e., that the NK cells had somehow been altered by virtue of competing for the targets. The demonstration that active NK cells of these patients recycled normally (Tables II and III) makes this hypothesis unlikely. Second, mixing experiments failed to demonstrate evidence of suppressor cells (Table IV). Third, analysis of the enzyme-substrate model for the CRA revealed that curves of the patients and controls on the double reciprocal

Table II. Derivation of Maximal Recycling Capacity

\begin{tabular}{|c|c|c|c|c|c|}
\hline Experiment no. & Subject & Slope & $r$ & $V_{\max }$ & MRC \\
\hline \multirow[t]{2}{*}{1} & Patient 1 & 1.39 & 0.9979 & 2,930 & 1.53 \\
\hline & Control 1 & 1.32 & 0.9999 & 31,100 & 8.89 \\
\hline \multirow[t]{2}{*}{2} & Patient 2 & 1.05 & 0.9601 & 1,620 & 2.38 \\
\hline & Control 2 & 1.13 & 0.9956 & 9,710 & 3.71 \\
\hline \multirow[t]{2}{*}{3} & Patient 3 & 1.45 & 0.9824 & 3,040 & 2.00 \\
\hline & Control 3 & 1.43 & 0.9986 & 5,590 & 2.88 \\
\hline \multirow[t]{2}{*}{4} & Patient 4 & 1.41 & 0.9984 & 3,950 & 3.59 \\
\hline & Control 4 & 1.28 & 0.9977 & 7,810 & 3.28 \\
\hline \multirow[t]{5}{*}{5} & Patient 5 & 0.91 & 0.9808 & 3,570 & 5.85 \\
\hline & Control 5 & 1.17 & 0.9998 & 12,300 & 3.35 \\
\hline & Patients & $1.24 \pm 0.11$ & & $3,020 \pm 398$ & $3.1 \pm 0.8$ \\
\hline & Controls & $1.27 \pm 0.05$ & & $13,300 \pm 4,606$ & $4.4 \pm 1.1$ \\
\hline & $P$ value & NS* $^{*}$ & & $P<0.05$ & $\mathrm{NS}^{*}$ \\
\hline
\end{tabular}

When CRA data are displayed on double reciprocal plots, straight lines are formed (e.g., Fig. 4). Slopes and correlation coefficients ( $r$ ) obtained by linear regression are shown here. The reciprocal of the y-intercept is the theoretical maximum number of targets ( $\left.V_{\max }\right)$ that could be killed by $1 \times 10^{5}$ effectors as the initial number of targets becomes infinite. Division of $V_{\max }$ by the percent active NK cells (Table I) $\times 10^{5}$ yields the MRC. All data are shown as mean \pm SEM. Note that although $V_{\max }$ and percent active NK cells (Table I) differ between groups, the quotient, MRC, does not. *NS, not significant. 


\begin{tabular}{|c|c|c|c|c|c|c|}
\hline Experiment no. & Subject & $\begin{array}{l}\text { Percent } \\
\text { targets } \\
\text { bound }\end{array}$ & $\begin{array}{l}\text { Percent lytic } \\
\text { conjugates } \\
\text { at } 4 \mathrm{hr}\end{array}$ & $\begin{array}{l}\text { Percent lysis } \\
\text { at } 4 \mathrm{~h} \text { solid } \\
\text { phase }\end{array}$ & $\begin{array}{l}\text { Percent } \\
\text { lysis at } 4 \mathrm{~h} \\
\text { fluid phase }\end{array}$ & ARI \\
\hline \multirow[t]{2}{*}{4} & Patient 4 & $22.7 \pm 2.0$ & 20 & 4.54 & 14.8 & 3.26 \\
\hline & Control 4 & $23.5 \pm 3.5$ & 25 & 5.88 & 25.9 & 4.40 \\
\hline \multirow[t]{4}{*}{5} & Patient 5 & $24.1 \pm 2.1$ & 14 & 3.37 & 14.3 & 4.24 \\
\hline & Control 5 & $23.0 \pm 2.5$ & 49 & 11.27 & 34.7 & 3.08 \\
\hline & Patients & $23.4 \pm 0.7$ & $17.0 \pm 3.0$ & $3.96 \pm 0.59$ & $14.6 \pm 0.3$ & $3.75 \pm 0.49$ \\
\hline & Controls & $23.3 \pm 0.3$ & $37.0 \pm 12.0$ & $8.58 \pm 2.70$ & $30.3 \pm 4.4$ & $3.74 \pm 0.66$ \\
\hline
\end{tabular}

NA (effectors) and K-562 tumor cells (targets) were mixed at a 5:1 ratio, and the percent of T cells which bound to E cells was counted (results expressed as mean \pm SD of triplicate samples). Lytic conjugates were determined as in Table I. The product of these two columns is the percent of targets which had been bound and lysed after $4 \mathrm{~h}$ of immobilization in agarose (the "solid" phase). The percent lysis in the fluid-phase CRA at an E:T ratio of 5:1 is also shown. Division of percent lysis in the fluid phase by that in the solid phase yields the ARI. Group data are shown as mean \pm SEM. Differences between patients and controls are not significant for any column, but it is clear that binding and recycling (ARI) do not differ between groups.

plots (Table II) were parallel straight lines (slopes of patients: $1.24 \pm 0.11$; slopes of controls: $1.27 \pm 0.05$ ). Using the analogy of enzyme kinetics, this suggested that there was "uncompetitive inhibition" (16), i.e., that formation of the bound intermediate (in this case, effector-target conjugates) was normal, but that formation of product (lysed targets) was diminished. Kinetics analysis therefore also indicated the presence of a postbinding defect.

This situation is similar to the NK defect in patients with the Chediak-Higashi syndrome where normal binding, defective postbinding lysis, and normal recycling have been described (14, 21). A heritable defect in NK activity is not part of the hemophilia diathesis, however, because our cryoprecipitate-treated patients, all of whom were HTLV-III seronegative (4), had normal NK activity (5).

One explanation for impaired NK activity that is consistent with epidemiologic findings in other AIDS risk groups is exposure to the AIDS virus. Although T helper lymphocytes are the primary target for HTLV-III, other cells can be infected (22), and it is conceivable that some NK cells are infected. Our study suggests, however, that hemophilia patients have fewer than half the expected number of active NK cells. Thus, if retroviral infection explained the increased number of inactive NK cells, a large percentage of NK cells would have to be infected. This is

Table IV. Mixing of Effector Cells

\begin{tabular}{llrrrr}
\hline & & \multicolumn{3}{c}{ Lytic units $\left(\mathrm{LU}_{30} / 10^{7}\right)$} \\
\cline { 3 - 6 } Experiment & Effector cell type & Control & Patient & $50: 50$ mixture & Expected \\
\hline A & NA & 473 & 19 & 223 & 246 \\
B & PBMC & 288 & 102 & 201 & 195 \\
C & NA & 85 & 26 & 51 & 56 \\
\hline
\end{tabular}

LU $(1 \mathrm{LU}=$ the number of effector cells required to attain $30 \%$ lysis of 5,000 K-562 targets) per $10^{7}$ effector cells were derived by linear regression analysis of CRA data (see Methods). Effector cells were either NA or PBMC. The expected number of LU for a 50:50 mixture of patient and control cells was the arithmetic mean of the patient and control LU values. There was no evidence of suppression within the mixed populations. not consistent with our present knowledge of $\mathrm{T}$ helper cell infection, where only a small minority of cells can be shown to be infected using in situ DNA hybridization (23). Another possibility is that a soluble inhibitor, or chronic lack of a soluble stimulator, is responsible for diminished NK activity. In this regard, NK activity of patients with AIDS or individuals at risk for AIDS $(19,20,24)$, including hemophiliacs $(9)$, has been responsive to lymphokines.

It is also possible that therapy with Factor VIII concentrates results in diminished NK activity through mechanisms other than HTLV-III infection. Impaired NK activity has been observed among individuals who had received multiple transfusions (25-27), some of whom were known to lack serum antibody to HTLV-III (27). In our experience, however, HTLV-III seronegative cryoprecipitate-treated patients, who have been exposed annually to plasma products obtained from hundreds of donors, had normal NK activity (5). We have also studied a small number of Factor VIII concentrate-treated patients who were HTLV-III seronegative. Although NK activity as assessed by chromium release was normal for the group, two of these five individuals had impaired NK activity (4). It is conceivable, however, that these seronegative individuals may represent instances of false negative serologies (28). Although we suspect that the abnormalities observed in seropositive hemophiliacs are related to HTLV-III infection, we cannot at present exclude a confounding or additive effect of Factor VIII therapy.

Our studies would indicate that some NK cells of HTLVIII seropositive hemophiliacs appear to kill and recycle normally and suggest a functional heterogeneity among the NK cell population. Heterogeneity within NK cells from normal individuals with respect to both cytolytic activity and surface phenotype has been described (29). Whether the phenotypic distribution within hemophilic NK cell populations differs from normals will await further study.

We have studied a group of asymptomatic hemophiliacs who have been treated with Factor VIII concentrates and are seropositive for antibody to HTLV-III. The impaired natural killer activity in these patients appears to be due to a defect in the postbinding lytic mechanism, with preservation of binding capability and recycling capacity. The mechanism and etiology of this localized defect are currently under investigation. 


\section{Acknowledgments}

The authors would like to thank Dr. Jerrold J. Ellner and Dr. Adel A. F. Mahmoud for their advice; Dr. Oscar D. Ratnoff for his advice and referral of patients; and Ms. Cheryl Inman for help in preparation of this manuscript.

These studies were supported in part by grants from the Northeast Ohio affiliate of the American Heart Association and the Templeton Fund. Dr. Katzman was supported by the National Research Service Award AI 07024. Dr. Lederman was a recipient of a New Investigator Research Award (AM 28324) from the National Institutes of Health.

\section{References}

1. Centers for Disease Control. 1985. Update: acquired immunodeficiency syndrome-United States. Mortality and Morbidity Weekly Report. 34:245-248.

2. Centers for Disease Control. 1984. Update: acquired immunodeficiency syndrome (AIDS) in persons with hemophilia. Mortality and Morbidity Weekly Report. 33:589-592.

3. Centers for Disease Control. 1985. Changing patterns of acquired immunodeficiency syndrome in hemophilia patients-United States. Mortality and Morbidity Weekly Report. 34:241-243.

4. Lederman, M. M., O. D. Ratnoff, B. L. Evatt, and J. S. McDougal. 1985. Acquisition of antibody to lymphadenopathy-associated virus in patients with classic hemophilia (Factor VIII deficiency). Ann. Intern. Med. 102:753-757.

5. Lederman, M. M., O. D. Ratnoff, J. J. Scillian, P. K. Jones, and B. Schacter. 1983. Impaired cell-mediated immunity in patients with classic hemophilia. N. Engl. J. Med. 308:79-82.

6. Porzsolt, F., M. Hanser, C. Piper, S. Scholz, H. Stotter, G. Pindur, E. Seifried, and H. Rasche. 1984. Impaired natural killer cell function in hemophiliacs with or without continuous substitution. Blut. 49:6165 .

7. Gjerset, G. F., P. J. Martin, R. B. Counts, L. D. Fast, and J. A. Hansen. 1984. Immunologic status of hemophilia patients treated with cryoprecipitate or lyophilized concentrate. Blood. 64:715-720.

8. Landay, A., M.-C. Poon, T. Abo, S. Stagno, A. Lurie, and M. D. Cooper. 1983. Immunologic studies in asymptomatic hemophilia patients. Relationship to acquired immune deficiency syndrome (AIDS). J. Clin. Invest. 71:1500-1504.

9. Lederman, M. M., O. D. Ratnoff, B. Schacter, and T. Shoger. 1985. Impaired cell-mediated immunity in hemophilia. II. Persistence of subclinical immunodeficiency and enhancement of natural killer activity by lymphokines. J. Lab. Clin. Med. 106:197-204.

10. Ratnoff, O. D., J. E. Menitove, R. H. Aster, and M. M. Lederman. 1983. Coincident classic hemophilia and "idiopathic" thrombocytopenic purpura in patients under treatment with concentrates of antihemophilic factor (Factor VIII). N. Engl. J. Med. 308:439-442.

11. Pross, H. F., M. G. Baines, P. Rubin, P. Shragge, and M. S. Patterson. 1981. Spontaneous human lymphocyte-mediated cytotoxicity against tumor target cells. IX. The quantitation of natural killer cell activity. J. Clin. Immunol. 1:51-63.

12. Grimm, E. A., and B. Bonavida. 1979. Mechanism of cell-mediated cytotoxicity at the single cell level. I. Estimation of cytotoxic $\mathrm{T}$ lymphocyte frequency and relative lytic efficiency. J. Immunol. 123: 2861-2869.
13. Ullberg, M., and M. Jondal. 1981. Recycling and target binding capacity of human natural killer cells. J. Exp. Med. 153:615-628.

14. Katz, P., A. M. Zaytoun, and A. S. Fauci. 1982. Deficiency of active natural killer cells in the Chediak-Higashi syndrome. Localization of the defect using a single cell cytotoxicity assay. J. Clin. Invest. 69: 1231-1238.

15. Steinhauer, E. H., A. T. Doyle, J. Reed, and A. S. Kadish. 1982. Defective natural cytotoxicity in patients with cancer: normal number of effector cells but decreased recycling capacity in patients with advanced disease. J. Immunol. 129:2255-2259.

16. Smith, E. L., R. L. Hill, I. R. Lehman, R. J. Lefkowitz, P. Handler, and A. White. 1983. Principles of Biochemistry: General Aspects. 7th ed. McGraw-Hill Book Co., New York. 184-188.

17. Lane, H. C., and A. S. Fauci. 1985. Immunologic abnormalities in the acquired immunodeficiency syndrome. Annu. Rev. Immunol. 3: 477-500.

18. Siegal, F. P., C. Lopez, G. S. Hammer, A. E. Brown, and S. J. Kornfeld. 1981. Severe acquired immunodeficiency in male homosexuals, manifested by chronic perianal ulcerative herpes simplex lesions. $N$. Engl. J. Med. 305:1439-1444.

19. Rook, A. H., H. Masur, H. C. Lane, W. Frederick, T. Kasahara, A. M. Macher, J. Y. Djeu, J. F. Manischewitz, L. Jackson, A. S. Fauci, and G. V. Quinnan, Jr. 1983. Interleukin 2 enhances the depressed natural killer and cytomegalovirus-specific cytotoxic activities of lymphocytes from patients with the acquired immune deficiency syndrome. J. Clin. Invest. 72:398-403.

20. Reddy, M. M., N. Pinyavat, and M. H. Grieco. 1984. Interleukin 2 augmentation of natural killer cell activity in homosexual men with acquired immune deficiency syndrome. Infect. Immun. 44:339-343.

21. Targan, S. R., and R. Oseas. 1983. The "lazy" NK cells of ChediakHigashi syndrome. J. Immunol. 130:2671-2674.

22. Montagnier, L., J. Gruest, S. Chamaret, C. Dauguet, C. Axler, D. Guetard, M. T. Nugeyre, F. Barre-Sinoussi, J.-C. Chermann, J. B. Brunet, D. Klatzman, and J. C. Gluckman. 1984. Adaptation of lymphadenopathy associated virus (LAV) to replication in EBV-transformed B lymphoblastoid cell lines. Science (Wash. DC). 225:63-66.

23. Hahn, B. H. 1985. Molecular biology of HTLV-III. Ann. Intern. Med. 102:807-809.

24. Lifson, J. D., D. F. Mark, C. J. Benike, K. Koths, and E. G. Engleman. 1984. Human recombinant interleukin-2 partly reconstitutes deficient in vitro immune responses of lymphocytes from patients with AIDS. Lancet. i:698-702.

25. Gascon, P., N. C. Zoumbos, and N. S. Young. 1984. Immunologic abnormalities in patients receiving multiple blood transfusions. Ann. Intern Med. 100:173-177.

26. Kaplan, J., S. Sarnaik, J. Gitlin, and J. Lusher. 1984. Diminished helper/suppressor lymphocyte ratios and natural killer activity in recipients of repeated blood transfusions. Blood. 64:308-310.

27. Kaplan, J., S. Sarnaik, and J. Levy. 1985. Transfusion-induced immunologic abnormalities not related to AIDS virus. N. Engl. J. Med. 313:1227.

28. Salahuddin, S. Z., J. E. Groopman, P. D. Markham, M. G. Sarngadharan, R. R. Redfield, M. F. McLane, M. Essex, A. Sliski, and R. C. Gallo. 1984. HTLV-III in symptom-free seronegative persons. Lancet. ii:1418-1420.

29. Lanier, L. L., A. M. Le, J. H. Phillips, N. L. Warner, and G. F. Babcock. 1983. Subpopulations of human natural killer cells defined by expression of the Leu-7 (HNK-1) and Leu-11 (NK-15) antigens. J. Immunol. 131:1789-1796. 